IZA DP No. 5383

Why Are Household Incomes More Unequally Distributed in China than in Russia?

Björn Gustafsson

Li Shi

Ludmila Nivorozhkina

December 2010 


\title{
Why Are Household Incomes More Unequally Distributed in China than in Russia?
}

\author{
Björn Gustafsson \\ University of Gothenburg \\ and IZA \\ Li Shi \\ Beijing Normal University \\ and IZA
}

Ludmila Nivorozhkina

Rostov State Economic University

Discussion Paper No. 5383

December 2010

IZA

P.O. Box 7240

53072 Bonn

Germany

Phone: +49-228-3894-0

Fax: +49-228-3894-180

E-mail: iza@iza.org

\begin{abstract}
Any opinions expressed here are those of the author(s) and not those of IZA. Research published in this series may include views on policy, but the institute itself takes no institutional policy positions.

The Institute for the Study of Labor (IZA) in Bonn is a local and virtual international research center and a place of communication between science, politics and business. IZA is an independent nonprofit organization supported by Deutsche Post Foundation. The center is associated with the University of Bonn and offers a stimulating research environment through its international network, workshops and conferences, data service, project support, research visits and doctoral program. IZA engages in (i) original and internationally competitive research in all fields of labor economics, (ii) development of policy concepts, and (iii) dissemination of research results and concepts to the interested public.
\end{abstract}

IZA Discussion Papers often represent preliminary work and are circulated to encourage discussion. Citation of such a paper should account for its provisional character. A revised version may be available directly from the author. 
IZA Discussion Paper No. 5383

December 2010

\section{ABSTRACT \\ Why Are Household Incomes More Unequally Distributed in China than in Russia?}

Harmonised microdata show a Gini coefficient for per capita total income of 45.3 percent in China 2002 and 33.6 percent in Russia 2003. A much larger urban to rural income gap in combination with a much smaller proportion of people living in urban areas in China are important reasons for this cross-country difference in inequality. Wage is a more nonequalising income source in China than in Russia. While Russian public transfers reduce income inequality, Chinese public transfers increase income inequality. Cross-country differences in the process of transition are also found to be significant. A relatively large nonagriculture self-employment sector is non-equalising in rural China, but is also narrowing the urban to rural income gap. In contrast to the many cross-country differences revealed, we report income inequality among urban residents in China and in urban Russia to be very similar.

JEL Classification: D31, P25, P52

Keywords: $\quad$ income distribution, inequality, China, Russia, public transfers

Corresponding author:

Björn Gustafsson

Department of Social Work

University of Gothenburg

P.O. Box 720

SE 40530 Göteborg

Sweden

E-mail: Bjorn.Gustafsson@socwork.gu.se 


\section{Introduction}

Among the countries in the world having had a socialist planning system, China and Russia are the most populous. In this paper we use two new large household surveys covering most parts of each country to compare the distribution of income, and find much more inequality in China. Our main research question is: Why, at the beginning of the millennium, is income inequality much larger in China than in Russia?

The major explanation we provide focuses on cross-country differences in urban to rural inequality. The gap in average income between urban and rural households is much larger in the still predominantly rural China than in the much more urbanised Russia. This is due to differences in economic development in combination with the strong restriction on rural to urban migration that has been in place in China for half a century. Wages are more disequalising in China as a whole then in Russia as a whole. While public transfers reduce income inequality in Russia, they are strongly disequalising in China as they almost exclusively benefit the better-off urban population.

While our explanation of why income inequality is larger in China than in Russia focuses on initial conditions of the transition from planned economy towards a market economy, we also report indicators of the differences during the transition playing a role. With the longest history of transition, rural China has a comparatively large sector of non-agriculture, selfemployed persons. As these persons typically earn more than average rural inhabitants, the sector has had disequalising effects on the rural income distribution. However, rural selfemployed residents typically earn less than urban residents and therefore non-agriculture selfemployment income acts to equalise income in China as a whole. Something similar cannot be reported for Russia.

In contrast to the considerable differences between China and Russia there are also similarities. Income inequality among urban residents in China and their counterparts in urban Russia is found to be very similar, and also similarly affected by public transfers. The positive effect of education of household head and the negative effect of household size on income are similar in both countries. Furthermore, children are on average less privileged compared to persons of other ages in both China and Russia. Yet, at the other end of the life cycle, the elderly are on average not worse-off compared to others in either of the countries. For Russia 
and urban China this is mainly an outcome of the pension system while for rural China, the background is that most elderly persons live with the younger generation.

To our knowledge, this paper is the first to compare income inequality at the household level in China and Russia using microdata. ${ }^{2}$ For both countries we use data from large surveys covering most of the countries; the Chinese data refers to 2002, the Russian data to 2003. We harmonise definitions and portray income inequality in each country. We report a Ginicoefficient of per capita total income for China of 45.3 percent while for Russia it is as low as 33.6 percent. We break down both samples into rural and urban regions and compare across countries. Such a breakdown also makes it possible to study the role of total inequality through differences in average income and population proportions in the two countries. In order to shed further light on reasons for the difference in income inequality across the two countries, we decompose the Gini coefficient by income sources using harmonised definitions. To understand how location, personal, and household characteristics are related to income in each country, we estimate income functions. This exercise makes it possible to study the magnitude of the urban to rural income gap after controlling for education and demographic factors. We find that the income return of living in an urban area is much higher in China, illustrating the large implications of restrictions for rural to urban migration.

The rest of the paper is laid out as follows: In the next section we provide the context for the comparison. The two datasets are described in Section 3 where we introduce assumptions used when analysing them. The theme for Section 4 is to depict overall income inequality and to decompose it between urban and rural regions. Section 5 defines components of income and uses them to decompose inequality. The regression analysis is reported in Section 6. The paper ends with a section summarising and discussing the findings.

\section{Context}

Although both China and Russia had very similar economic systems, China was at a rather low stage of economic development when it adopted the "Soviet" planning model in the 1950s. This model treated the urban and the rural populations differently. In urban areas a very high proportion of the population was employed as workers, almost exclusively in stateand collectively-owned enterprises to which the workers had life-long relations. They received subsidised housing, pensions, other social insurance benefits, in-kind payments and 
modest earnings. Income taxes were low as the public budget could rely on surpluses from the state-owned units. The urban population was the privileged segment of society, a segment much larger in Russia than in China.

In the Soviet model, the organisation of production in the rural regions was different from that in the urban areas. Adult rural individuals were typically members of collective units and thereby their incomes were determined as residuals. As they were not employed in the state sector, rural persons had to provide their own housing and were not covered by social insurance systems. During the initial phases of industrialisation, farmers in both countries had to deliver agriculture products at low prices while prices for manufactured goods were comparatively high. Forceful restrictions (in the Soviet Union the system of Propiska and in China the Hukou system) acted as barriers which prevented rural people from migrating to cities and thereby kept the urban to rural income gap artificially high. This has particularly been the case in China, where the household registration system has been in effect for half a century. ${ }^{3}$

When transition to a market economy began, circumstances in rural areas of China and Russia were rather different. Chinese agriculture had very much the character of labour-intensive production for self-consumption while in Russia agriculture was much more mechanised and specialised. Some persons active in agriculture in Russia were employed in state-owned farms earning wages. Furthermore, the members of the Soviet kolkhoz were integrated into the state welfare system receiving retirement pensions, minimum wages and health insurance. As opposed to China, most of the agriculture products in Russia were consumed in the urban regions. Although we are not aware of any detailed comparative study, one can claim that at the onset of transition the urban to rural income gap was much higher in China (a country then at an early stage of industrialisation) than in Russia. True, living standards in rural China have improved during transition while they deteriorated during the 1990s in rural Russia, making cross-country differences smaller (Herrold-Menzies, 2009). However, urban incomes have moved in the same direction as rural incomes for both countries: in China, rapid increases, and in Russia, rapid decreases for several years followed by increases. As a consequence the urban to rural income gap has continued to be larger in China than in Russia.

The first steps in transition towards a market economy were taken in the late 1970s in the rural areas of China and were followed in the urban areas in the mid 1980s. China's transition 
has taken place during an episode of rapid economic growth as well as rapid urbanisation. Life expectancy has increased to be actually longer than in Russia. One key element for change, which has not appeared in Russia to the same extent, has been policies of opening up the economy for foreign trade and investment. Such measures were first implemented in the eastern region of the country, deliberately creating spatial income differences which public policy later has aimed to narrow.

While the first steps toward a market economy were taken later in Russia, its privatization came earlier through mass privatization (1992-1994) and the introduction of formal property rights. The changes in the two countries took place in rather different environments, as well. Russia, as opposed to China, combined movement towards a market economy with steps towards western-style political democracy. In contrast to China, the steps towards a market economy in Russia during the 1990s took place simultaneously with the erosion of institutions. For many years after the Soviet Union had dissolved, Russia experienced rapid negative economic growth and large falls in real wages. The macroeconomic collapse was accompanied by a reduction in life expectancy. In the mid-1990s and parallel to the development in urban China, unemployment in Russia surfaced and many workers left the labour force - two outcomes of economic restructuring. However, during the beginning of the new millennium, the Russian economy experienced positive growth, a change connected to the rising prices of oil and other natural resources with which Russia is endowed.

In this paper we show that public transfers affect income inequality rather differently in China and Russia. One important reason for this is the larger urban to rural income gap. This is reinforced by differences in pension systems across the countries. The Soviet Union introduced modest pensions for its rural elderly, while up to now this has not been the case for China. In post-Soviet Russia a considerable proportion of voters have been made up of the elderly, and therefore it is not surprising that pension levels has remained a hot issue. According to the new pension law which came into effect in January 1992, all persons are entitled to an old-age pension when reaching the qualifying pension age (60 for men and 55 for women). We show that within the urban areas of the two countries where the systems are similar, transfers are equalising. This is also the case in Russia as a whole. In contrast, public transfers are strongly disequalising in China as a whole where public transfers benefit mainly the privileged urban population. 
In recent empirical research there are many studies analysing how income inequality has changed in each of the two countries. For China, the literature shows that income inequality has been on the rise during much of the transition period. This process, however, seems not to be smooth. A common theme in the literature is the importance of spatial differences, primarily the urban to rural dimension. ${ }^{4}$ Much has also been written on income inequality in Russia during its transition. However, for Russia the facts have been considerably more difficult to establish due to data issues. The limitations of official data are large and research initialised data collections, although useful in shedding light on many questions, have not provided a complete substitute. ${ }^{5}$

\section{Data and assumptions}

The Chinese data for this study comes from two coordinated household surveys conducted for the research project "Income Distribution, Growth and Public Policy in China”, which involved a group of researchers at the Institute of Economics, Chinese Academy of Social Sciences, Beijing and scholars from other countries. It was economically supported by the Ford Foundation in Beijing and SIDA (Swedish International Development Agency). The project was assisted by the General Team of Rural Surveys and General Team of Urban Surveys at the National Bureau of Statistics (NBS) that conducted the fieldwork in the beginning of 2003, and income refers to $2002 .{ }^{6}$ NBS uses different samples and survey instruments for rural and urban China, which is also the case for our data. The questionnaires were designed by the project team to meet the needs of research. The surveys of urban residents include the province level units Beijing, Shanxi, Liaoning, Jiangsu, Anhui, Henan, Hubei, Guangdong, Chongqing, Sichuan, Yunnan, and Gansu. A sample of 6835 households living in 77 cities was derived from larger samples regularly used by NBS to produce official statistics for China. The rural sample includes Beijing, Hebei, Shanxi, Liaoning, Jilin, Jiangsu, Zhejiang, Anhui, Jiangxi, Shandong, Henan, Hubei, Hunan, Guangdong, Guangxi, Chongqing, Sichuan, Guizhou, Yunnan, Shaanxi, Gansu and Xinjiang. From these province level units, 122 counties or country-level cities were selected and from them 9200 households. The rural and urban samples were selected with different sampling probabilities. To correct for this we used sample weights for urban and rural samples according to the proportion of actual population in urban and rural areas. 
Probably the largest limitation with the Chinese survey is that it does not cover rural households which reside in urban areas without an urban register, a hukou. Well-founded estimates of its size are not available, but most observers agree that it has increased rapidly. The non-coverage of the rural, often temporary, population living in urban areas is a property shared by most other studies of income inequality in urban China. It means that we most likely underestimate income inequality in urban China, as temporary migrants typically earn less than the registered population. However, available evidence indicates that in the distribution of income in China as a whole, the temporary rural to urban migrants can be found in the middle of the distribution. This means that our estimates of income inequality in China as a whole are probably not seriously biased by the limitation in the sampling process. ${ }^{7}$

The Russian data comes from the National Survey of Household Welfare and Participation in Social Programs, also known as NOBUS (after its Russian acronym). It was developed with the technical assistance of the World Bank and administered by the Federal Service of State Statistics (Rosstat) in the 2nd quarter of 2003. The survey uses a random sample of 44529 households and 107695 individuals that was created using a multi-stage stratification, i.e. sequential random selection with a two-phase selection. First, seven types of urban settlements (strata) were defined by population size, as well as one strata of rural settlements, and then sampled. ${ }^{8}$ In a later stage households were selected from addresses. In order to arrive at estimates for the population we apply the sample weights that were developed by the data producers. As opposed to the Chinese data, the same survey instrument was used for urban and rural households alike. Some comparisons of population characteristics according to NOBUS and the All-Russian population census autumn 2002 show no larger differences. ${ }^{9}$

Estimates on income inequality in post-Soviet Russia differ greatly between sources, and often such differences do not seem to be driven by differences in period covered. While earlier estimates pointed in the direction of post-Soviet Russia as a country with much income inequality, more recent estimates sometimes do not. The shift can be seen in the different issues of the World Bank's World Development Report. While the World Development Report 2000/2001 reported a Gini of 48.7 percent in 1998, the World Development Report 2006 reported a Gini (for consumption expenditures) amounting to as little as 32.0 percent in 2002. This difference in the Gini of as much as 16.7 percent units must chiefly be the outcome of differences in data and/or definitions, as the alternative interpretation of an extremely rapid 
equalisation process over the four years would not have taken place largely unnoticed by observers. $^{10}$

There are many technical reasons why estimates on income inequality in post-Soviet Russia differ, even when relating to the same year, and the issue deserves an analysis of its own. Here we limit ourselves to mention some critical issues, referring the interested reader to World Bank (2005B) and Yemtsov (2008) for more details. One central point is that official Russian estimates are based on money income, while NOBUS allows us to also include transfers received in kind (corrected for regional prices) as valued by the data provider. This difference is rather important as in post-Soviet Russia, transfers in kind are more equally distributed than money income. Second, our definition of income also includes imputed rents of owner-occupied housing. If we replace our definition of disposable income, which is more comparable with that used in studies for other countries, with that used in the official statistics in Russia, we arrive at a much higher Gini than that reported later in this paper. ${ }^{11}$ Third, Federal State Statistics Service (Rosstat) uses procedures to correct for possible underreporting of income among high income earners and for shadow incomes, while we do not. While our choice perhaps causes us to underestimate the extent of income inequality, attempts to make corrections can be expected to include other errors that are not necessarily smaller than those motivating the corrections. ${ }^{12}$

The two surveys were conducted independently of each other. We have ex-post harmonised definitions for the two surveys. The basis for this work was provided by documents and questionnaires of the two surveys, as well as knowledge accumulated by the authors when actively involved in the data collection processes. However, comparability across the surveys is not perfect. For example, it can be noted that the Russian sample comprises many more households, meaning that estimates are potentially more precise. On balance we cannot conclude whether the differences in inequality across China and Russia reported here are underestimates or overestimates. ${ }^{13}$ However, the differences reported here in income inequality across the two countries with ex-post harmonised definitions are so large that it would be very difficult to argue that they are caused by differences in the data generating process only.

We define total income for each household as the sum of income components such as wages, farming income, non-agriculture self-employment income, public transfers, privately provided transfers, imputed rent of owner-occupied housing, and housing subsidies. Income can be 
received as money in kind, constitute the net output of self-subsistence agricultural production or be the value of residing in a private home. ${ }^{14} 15$ For each household we divide total income by the number of household members. ${ }^{16}$ Following the prevailing praxis when analysing the distribution of income in rich countries, we assign the resulting per capita total income to each household member and study the resulting variable per capita total income. This means that while the household is the income-receiving unit, the individual is the analytical unit.

\section{Overall inequality and decomposition by urban and rural regions.}

/Figure 1 and Figure 2 about here/

We use graphs to provide a first impression of the distributions of income in the two countries. Figure 1 illustrates histograms where each bar shows proportion of individuals by fractions of mean income. It shows clearly that the Chinese distribution is much more unequal than the Russian. In China the largest concentration of individuals is in the interval 20 percent to 60 percent of mean income, while in Russia the largest concentration of individuals is in the interval 40 percent to 90 percent of mean income. In Figure 2 (for China) and Figure 3 (for Russia) we have broken down the two samples into rural and urban regions and find large differences across countries. The largest proportion of urban Chinese households has incomes that are at least 150 percent or more of the country mean; few are below 70 percent of the country mean. The situation in rural China is rather different as the majority have incomes below 70 percent of the country mean and only a very few reach up to 150 percent or more of the country mean. There is clearly much more overlap between the urban and rural income distributions in Russia, although having an income above the mean is much more common for urban inhabitants. ${ }^{17}$

\section{/Table 1 about here/}

In Table 1 we tabulate Lorenz-curves and report selected inequality indices for total per capita income in China and Russia, as well as for each country’s rural and urban regions. Clearly the Lorenz-curve for China as a whole indicates a more unequal distribution than for Russia as a whole and the Gini-coefficients amount to 45.3 percent and 33.6 percent. Other large differences across the two countries according to our data as shown in Table 1 are that while as many as 75 percent of the population in Russia is urbanized, the corresponding proportion 
in China is only 39 percent. Furthermore, while the income gap between urban and rural areas is as high as 3.05 in China it is not more than 1.67 in Russia. ${ }^{18}$

How do these inequality estimates relate to others reported for the two countries for approximately the same years? Starting with China, OECD (2004) cites a National Bureau of Statistics estimate of 41.7 percent for 2000. For $2001 \mathrm{Wu}$ and Perloff (2005) report a Gini of 41.5 percent while for the same year Ravallion and Chen (2007) report a Gini of 44.7 percent. Based on varying the definition of income in our data, we find that one important reason for our estimate being higher is that our definition of income is broader and more justified as it includes imputed rents from owner-occupied housing.

Turning to the Gini for Russia, it can be noted that the World Income Data Base (version 2.0 June 2005) at the World Institute for Development Economic Research (WIDER) has compiled as many as 47 Gini coefficients obtained from different surveys (using different samples and definitions) referring to the period 1981 to $2002{ }^{19}$ The Gini of 33.6 percent we report for 2003 is higher than those referring to the Soviet epoch (that is, up to 1991). In contrast many later estimates of the Gini coefficient for Russia are higher than ours. However, some close to ours have also been reported. ${ }^{20}$

While overall income inequality is much larger in China than in Russia, when moving to the two sub-national levels there are also similarities. In both countries urban inequality is lower than rural inequality. The inequality indices take higher values for rural areas in China than in the rural areas of Russia, and with the exception of the first decile, the Lorenz-curve is higher for rural Russia. A striking similarity across countries appears in urban areas and the Lorenzcurves for urban China and urban Russia are virtually identical. The Gini of 31.7 percent for urban China and 31.4 percent for urban Russia are comparable to what is reported for many rich countries during approximately the same time period, according to the Luxembourg Income Study (LIS) ${ }^{21}$. It also means that the Ginis for urban China and urban Russia are lower than reported for the United States as a whole, but higher than reported for some low inequality countries in Europe. ${ }^{22}$

In order to shed more light on differences between China as a whole and Russia as a whole, we decompose total income inequality in each country using additively decomposable inequality indices. An additively decomposable inequality index has the property that when breaking down the population under study into mutually exclusive subgroups, total inequality 
is equal to the weighted sum of inequality in each subgroup and a term representing "between group inequality”. "Between group inequality” indicates how large an amount of inequality would remain if mean income of the subgroups were the same, but inequality within each subgroup was kept unchanged. The magnitude of the "between group inequality" component is in turn dependent on the size of the difference in mean income across groups as well as the population's distribution across subgroups.

/Table 2 about here/

We have computed the Mean Logarithmic Deviation as well as the Theil index where the former uses population shares to weight within group inequality and the latter uses income shares. The results are shown in Table 2. For both indices as much as 43 percent of total income inequality in China as a whole can be attributed to between urban and rural inequality, while only 11 or 10 percent (depending on index) of the smaller total income inequality in Russia can be attributed to between urban and rural inequality. The "between urban and rural inequality” component is as much as seven times larger in China than in Russia. ${ }^{23}$

\section{Decomposing income inequality by income sources}

In this section we analyse why income inequality is larger in China by decomposing the Gini coefficient for total per capita income by income sources. The Gini coefficient can be written as the weighted sum of the concentration coefficients for the various income sources. The weights are the relative shares of the income source in total per capita income so we have:

$$
G=\sum_{k} \frac{\mu_{k}}{\mu} C_{k}
$$

where $\mu_{k}$ and $\mu$ are the means of income source $k$ and total per capita income, and $C_{k}$ is the concentration coefficient of income source $k$. The concentration coefficient measures the association between income source $k$ and total per capita income with values ranging from -1 to +1 . If the concentration coefficient is negative it means that low-income earners are receiving larger amounts (in absolute sense) than high-income earners. However, not only the sign of the concentration coefficient is of interest, but also its magnitude in comparison to the Gini coefficient, as an indictor of the distributional profile of the income source. If the income 
source has a concentration coefficient that is equal to the value of the Gini coefficient of total per capita income, the distribution of the income source is as equal as the total per capita income. However, if the concentration coefficient of an income source is greater (smaller) than the Gini coefficient of total per capita income, this income source is considered to be disequalizing (equalizing).

The relative contribution of income source $\mathrm{k}$ to income inequality is expressed as:

$$
E=u_{k} C_{k} / G
$$

where $u_{k}$ is share of income source $k$ in total per capita income, $C_{k}$ is the concentration coefficient of income source $k$, and $G$ is the Gini coefficient of total per capita income.

In addition, the difference between two Gini coefficients for different countries can be written as:

$$
G_{1}-G_{0}=\sum\left(u_{1 k} C_{1 k}-u_{0 k} C_{0 k}\right)
$$

where $u_{i k}$ is the share of income source $k$ in total per capita income in country $i$ (China and Russia), $C_{i k}$ is the concentration coefficient of the income source $k$ in country $i$, and $G_{i}$ is the Gini coefficient of equivalent disposable income in country $i$ (China and Russia).

/Table 3 about here/

We define for both countries as similar as our data allows six income components (and in the Chinese data a small residual component). Table 3 reports the results for China as a whole and Russia as a whole and we comment first component by component before turning to how the decomposition can throw light on the cross-country difference in income inequality (Table 4). In both countries, wages make up half of total per capita income. They are disequalising in both countries, though more so in China. The latter can be understood from the fact that wages are concentrated to the urban areas as seen in Tables 5 and 6 where we decompose income inequality in urban and rural regions by source. Non-agriculture self-employment income is one of the smaller income sources in China as a whole and very small in Russia, according to our data. The component is equalising in China as a whole due to a considerably larger share in the rural regions (compare Table 6 and Table 5). Farm income is defined as income from agricultural production on land the household has user rights to, irrespective of whether the products are self-consumed or sold. They make up 13 percent of total per capita 
income in China, and not surprisingly, the relative share is less than half as large in Russia. Farm income is more equalising in China.

Public transfers make up as much as 18 percent of total per capita income in Russia as a whole, but only half as much in China as a whole. In Western countries public transfers are typically equalising which is also the case in Russia where the concentration coefficient is found to be as low as 0.18 , indicating only a weak positive relation between public transfers and total income. Unlike in Russia, public transfers in China as a whole have a concentration coefficient as high as 0.67 and are thus strongly disequalising. This shows that it is the more affluent urban residents, not the disadvantaged rural inhabitants, who are benefiting from public transfers. In contrast, private transfers in China make up a larger proportion of total income than in Russia and with a concentration coefficient of 0.21 , are equalising. Tables 5 and 6 show that private transfers are much more important for the worse-off rural households in China than for the urban households. Probably a considerable proportion of the private transfers in China are constituted of remittances from rural migrants back to their families, an issue that deserves further study. Finally, in our data and with our definitions, we report that the income source imputed rents and housing subsidies comprise far from a trivial proportion of total income in both countries and it is non-equalising.

\section{/Table 4 about here/}

We now turn to Table 4 showing how the decomposition throws light on the difference in Gini for total per capita income between China and Russia. We find that differences in concentration coefficients dominate differences in relative shares. If wages in China had had the same distributional profile as in Russia, the gap in Gini between the two countries under study would have been halved (from 12 to 6 percent units). If public transfers in China had had the same distributional profile as in Russia, the gap in Gini would have been reduced by 4 percentage points if evaluated by the income share in China, but by as much as 9 percentage points if evaluated by the higher Russian income share. If imputed rents and housing subsidies had the same distributional profile in China as in Russia, the gap in Gini would narrow by 3 alternatively 4 percentage points. One example of an income source working in the opposite direction is farm income being more concentrated to low-income persons in China than in Russia, while the other example is non-agriculture self-employment income. However, each of these is separately of minor importance, as replacing the Chinese coefficient with the Russian would narrow the gap in Gini by at most 2 percentage points. 
/ Table 5 and Table 6 about here/

The decomposition of the equally large Ginis for urban regions in China and Russia reported in Table 5 shows some interesting differences. Wages make up a somewhat larger share of total per capita income in urban China than in urban Russia. Wages are slightly equalising in urban China but disequalising in urban Russia. Public transfers are equalising in both countries, and more so in urban Russia. Private transfers are fairly small in the urban regions of both countries. Imputed rents and housing subsidies are disequalising in urban China, but not in urban Russia. Possible reasons for this difference could be that China is much more densely populated leading to high market prices on housing, in combination with differences in how the privatisation process has taken place.

Finally the decompositions for rural regions in Table 6 provide some additional insights. There are many differences to comment on which reflect the different situations in the two countries. The difference in organization is apparent in wages having the largest income share in rural Russia, while this role is assumed by farm income in rural China. Farm income is remarkably equally distributed in rural China, while not so in rural Russia. On the other hand, the long period of transition in rural China is visible in a much larger share of income from non-agriculture self-employment than in Russia, and is also large compared to what was found in urban China. Rather strikingly, the income share of public transfers in rural Russia is as high as 24 percent and the component is equalising within rural Russia. In contrast, the income share of private transfers in rural China is as high as 14 percent. ${ }^{24}$ Private transfers in rural China have a profile that is inequality generating in rural China. In contrast the income share of private transfers in rural Russia is only 5 percent.

\section{Characteristics and income}

In this section we compare the income situation for people with different characteristics living in China and Russia by estimating income functions. Explanatory variables measure age and gender of the person, education of household head, number of household members, and an urban dummy as well as regional dummies (three for China and six for Russia). Descriptive statistics for China are presented in Table 7 and for Russia in Table 8. The tables also report variable by variable on the composition of the sample at the bottom 20 percent and top 20 
percent, thus making it possible to see what characterises persons at the two tails of the income distribution.

\section{/Tables 7 and Table 8 about here/}

Starting with age of individual we note a somewhat larger proportion of children in the Chinese sample. In both countries children are overrepresented in the lowest quintile, underrepresented in the highest. While many Western countries have relatively ambitious systems of family allowances, such programs are not found in China or Russia. In contrast, we do not find signs indicating that the elderly in China and Russia, of whom many live in three-generation households, are on average less privileged than persons of other ages. As could be expected, the Russian household heads are on average longer educated than the Chinese, and we report positive relations between education and the proportion belonging to the highest quintile for both countries. Consistent with what population statistics show, we report a considerably higher proportion of females than males in the Russian sample, while in the Chinese sample gender composition is more balanced. Household size is typically larger in the Chinese data. Finally, turning to region we report that two-thirds of persons in the top quintile in the Chinese distribution live in the eastern region and that two-fifths of persons in the top quintile for Russia live in the central region (which includes Moscow). At the other end of the income distribution, a slight majority of the Chinese sample live in the Western region and the same applies to the southern region or the Volga region in the Russian sample

/Table 9 about here/

In Table 9 we report OLS estimates of log-income functions using the same specification for the two countries in order to better understand the relation between characteristics and equivalent income. Several comments are motivated. First, not surprisingly, location is of consequence in both countries even after controlling for the various household and individual level variables. ${ }^{25}$ The coefficient for the urban dummy is estimated with high t- statistics in both countries and the coefficient for China is more than two times as high as the coefficient for Russia. This is consistent with the common knowledge that in China there are large potential benefits for rural persons to migrate to a city. Not surprisingly in two of the largest countries in the world, we find that region influences income. Starting with Russia, we report small positive coefficients for living in the Northwestern region and the Far East compared to the base category, the Central region. This is consistent with occupational wages often being 
higher in these regions. The largest negative coefficients for Russia are reported for the Southern region and the Volga region. However, the magnitudes of the coefficients for the Central and Western regions of China are still larger. We have thus found that as measured here, location can have a larger influence on a person's income in China than in Russia.

Second, education of household head is significant in both countries. While previously reported results from analyses of wages would have led one to expect higher coefficients for Russia, ${ }^{26}$ most coefficients reported here are actually higher for China. A probable reason for this is that education has a larger effect on who earns wages and thereby yields a relatively high per capita income in China than in Russia. The results indicate that private benefits for investing in schooling are common to the two countries. Third, we find income to increase by age in both countries up until age 46-55 after which it decreases. The first part of the profile is steeper in Russia, while this is not the case at higher ages. When running separate equations for rural and urban sub-samples of the two countries, we can attribute much of the later difference to the rural regions. In rural Russia, where our data shows that most elderly people receive pensions, age does not negatively affect income after age 55 as it does in rural China. Fourth, we find household size to negatively affect per capita total income in both countries and the coefficients are somewhat higher in China. Finally, the negative coefficient of female gender is estimated with a high t-statistic but is small in both countries.

\section{/Table 10 about here/}

Based on the estimates we predict log income for selected typical persons, transform the predictions into Yuan and Roubles respectively, and finally express these values as percent of the mean value as it is observed in the data. We do this for four combinations of rural-urban and rich-poor regions for each country and report the numbers in Table 10. Our base individual is aged 36-45, lives in a household of three and the male head has a middle-long education. Such an individual living in China has an above-average income with the exception of an individual living in a poor rural region. In contrast, the individual reaches above-average in Russia only if urbanised and living in a rich region. This cross-country comparison illustrates that individuals in Russia are on average better endowed with income generating characteristics than their Chinese counterparts.

The predictions also illustrate the rather substantial income differences due to location only. If the typical person lives in a rich urban are, not in a poor rural area, income more than triples 
in China and more than doubles in Russia. Compared to the spatial differences, differences due to varying household characteristics are substantially smaller. This is illustrated when changing household size (case individual b) and education of household head (case individual c). The age-related variation is also small (case individuals $\mathrm{d}$ and e).

\section{Conclusions}

In this paper, using harmonised microdata we have studied income inequality in China and Russia at the beginning of the new millennium. We find income to be much more unequally distributed in China, and report for the entire country a Gini coefficient of 45.3 percent for total per capita income 2002, while according to our data, the Gini for Russia is as low as 33.6 percent in 2003. The latter is considerably lower than several previous estimates reported for Russia in transition, but not uniquely low. Understanding this difference was the major task of our paper. Therefore we described the distributions of total per capita income, decomposed inequality in each country into urban and rural inequality, decomposed the Gini coefficient of total per capita income by income source and also estimated regression models with log income as the dependent variable using the same specification for both countries investigated.

According to the analyses presented here, China's much larger urban to rural divide is a major reason why income inequality is much higher in China. This can to a large extent be traced back to differences in economic development. That the degree of economic development has a strong impact on the distribution of income is also a conjecture which Simon Kuznets formulated half a century ago (see Kuznets, 1955), and has been the point of departure for much research on income inequality. However, a difference in economic development is not the only reason why the urban to rural income gap at the beginning of the 2000s is larger in China than in Russia. Ever since the beginning of the 1960s in China, the hukou system has been a stronger barrier than its Russian counterpart. It has prevented rural inhabitants from moving to the cities and consequently, the urban to rural income gap from narrowing. While 75 percent of the Russian inhabitants were living in cities when our data was collected, the corresponding proportion in China was only 39 percent. We report that while urban average income was as large as 3.1 times rural income in China, the corresponding number in Russia was only 1.7. Our regression analyses show that although differences in individual and household characteristics can account for part of these differences, a pure effect of residing in 
an urban area remains and has a larger magnitude in China. The great importance of the rural to urban divide in China is illustrated by results from computing an additively decomposable inequality index. As much as 43 percent of inequality in the distribution of income in China as a whole would vanish, if mean income of rural China and urban China were the same, while keeping inequality within rural and urban China constant. For Russia, the corresponding proportion of the smaller inequality is much smaller.

The larger urban to rural income gap and the smaller proportion of people living in urban areas in China means that wages are a more non-equalising income source than in Russia. While Russian public transfers reduce income inequality, Chinese public transfers increase income inequality. An important reason for this difference is that while rural elderly in Russia receive pensions, this is not the case in China.

While differences in initial conditions go a long way to explain why income inequality is larger in China than in Russia, we have also found differences in the process of transition. During the more than two decades of transition in rural China, a sector of non-agriculture selfemployed households has grown. This has, on one hand, contributed to making the distribution of income in rural China more unequal than in rural Russia. On the other hand, according to our accounting exercise, the expansion of the sector has also narrowed the urban to rural income gap and thereby reduced income inequality in China as a whole.

Despite the many differences in the income and inequality generating process between China and Russia, there are also similarities. Inequality in income among urban residents in China and urban inhabitants in Russia was found to be surprisingly similar. In both countries household income is positively affected by education of household head and negatively by household size; and the relations are similar in magnitude in the two countries. In both countries, children make up the age group that is worse-off compared to other age groups. Yet, at the end of the life cycle, the elderly are on average not worse-off than others. For Russia and urban China this is most likely the outcome of the pension system. Still, in rural China, living with the younger generation in a household which is likely to receive private transfers seems to be the main reason why the elderly are on average doing as well as people of other ages. 


\section{References}

Atkinson, A. \& Micklewright, J. (1992) Economic Transformation in Eastern Europe and the Distribution of Income, Cambridge: Cambridge University Press.

Brandt, L. and Holz, C. (2006) "Spatial Price Differences in China: Estimates and Implications”, Economic Development and Cultural Change, 55, 43 - 86.

Carluer, F. (2005) "Dynamics of Russian Regional Clubs: The Time of Divergence”, Regional Studies, 39, $713-726$.

Commander, S., Tolstopiatenko, A. \& Yemtsov, R. (1999) "Channels of Redistribution. Inequality and Poverty in the Russian Transition", Economics of Transition, 7, 411 - 447.

Fleisher, B., Sabirianova, K and Wang, X. (2005) "Returns to Skills and the Speed of Reforms: Evidence from Central and Eastern Europe, China, and Russia”, Journal of Comparative Economics, 33, (2) 351 - 370.

Galbraith, J., Krytynskaia, L. and Wang, Q. (2004) "The Experience of Rising Inequality in Russia and China during the Transition”, European Journal of Comparative Economics, 1 (1) $87-106$.

Gustafsson, B., Li S., Nivorozhkina, L. and Katz, K. (2001) "Roubles and Yuan: Wage Functions for Urban Russia and China at the end of the 1980s", Economic Development and Cultural Change, 50 (1) 1 - 17.

Gustafsson, B. and Nivorozhkina, L. (2005) "How and Why Transition Made Income Inequality Increase in Urban Russia: A Local Study”, Journal of Comparative Economics, 33, $772-787$.

Gustafsson, B., Li, S. and Sicular, T.. (Eds) (2008) Inequality and Public Policy in China, Cambridge: Cambridge University Press.

Herrold-Menzies, M. (2009) “The Post-Collective Village: A Tale of Two Transitions", World Development, 37 (1) $232-241$.

Khan, A. and Riskin, C. (2008) "Growth and Distribution of Household Income in China between 1995 and 2002 ” Chapter 3 in Gustafsson, B. Li, S. and Sicular, T. (Eds) Inequality and Public Policy in China, Cambridge: Cambridge University Press.

Knight, J. and Song, L. (1999) The Rural - Urban Divide. Economic Disparities and Interactions in China, Oxford: Oxford University Press.

Kislitsyna, O. (2003) "Income Inequality in Russia During Transition. How Can It be Explained?, Moscow, Economic Education and Research Consortium, Working Paper Series No 03/08.

Kuznets, S. (1955) "Economic Growth and Income Inequality”, American Economic Review, $45,1-28$. 
Li, S., Luo, C., Wei, Z., Yue, X. (2008) “The 1995 and 2002 Household Surveys: Sampling Method and Data Description” Appendix in Gustafsson, B. Li, S. and Sicular, T. (Eds) Inequality and Public Policy in China, Cambridge: Cambridge University Press.

Mikheeva, N. (1999) "Differentiation of Social and Economic Situation in the Russian Regions and Problems of Regional Policy” Economic Education and Research Consortium. Russian Economic Research Program Working Paper No 99/09.

Milanovic, B. (1998) Income, Inequality, and Poverty during the Transition from Planned to Market Economy, Washington, D.C. The World Bank (Regional and Sectoral Studies)

Mitra, P. and Yemtsov, R. (2006) "Increasing Inequality in Transition Economies: Is There More to Come?” World Bank Policy Research Working Paper 4007.

Nee, V. (1989) "A Theory of Market Transition: From Redistribution to Market in State Socialism”, American Sociological Review, 54 (5), 663 - 681.

Organisation for Economic Co-operation and Development (OECD) (2004), Income Disparities in China. An OECD Perspective, Paris.

Ravallion, M. and Chen, S. (2007) “China’s (Uneven) Progress against Poverty”, Journal of Development Economics, 82, 1 - 42.

Sicular, T., Yue, X, Gustafsson, B. and Li, S (2007) “The Urban - Rural Income Gap and Inequality in China”, Review of Income and Wealth, 53, (1), 93 - 126.

Secondi, G. (1997) "Private Monetary Transfers in Rural China: Are Families Altruistic?”, Journal of Development Studies, 33, 487 - 511.

Sheviakov, A. Y. and Kiruta, A., Y. (2001) "Economic Inequality, Standards of Living, and Poverty in Russia: Measurement and Causal Dependencies”, Economic Education and Research Consortium.

United Nations Development Program (UNDP) (2005), China Human Development Report, 2005. Development with Equity.

Whyte, M. K. (2010) One Country, Two Societies. Rural-Urban Inequality in Contemporary China, Cambridge Mass: Harward University Press, Harvard Contemporary China Series 16.

World Bank (2000) World Development Report 2000/2001. Attacking Poverty, Washington: World Bank and Oxford: Oxford University Press.

World Bank (2005A) World Development Report 2006: Equity and Development, Washington: World Bank and Oxford: Oxford University Press.

World Bank (2005B) Russian Federation: Reducing Poverty through Growth and Social Policy Reform, Report No 28923-RU. Poverty Reduction and Economic Management Unit Europe and Central Asia Region. 
Wu, X. and Perloff, J. (2005) “China's Income Distribution, 1985 - 2001”, Review of Economics and Statistics, 87 (4) $763-775$.

Verhoeven, W - J, Jansen, W and Dessens, J. (2005) "Income Attainment During Transformation Processes. A Meta-analysis of the Market Transition Theory”, European Sociological Review, 21 (3), 201 - 226.

Yemetsov, R (2005) “Quo vadis: Inequality and Poverty Dynamics Across Russian Regions in 1992 - 2000” in Kanbur, R, Venegles, A. (Eds) Spatial Inequality and Development, Oxford: Oxford University Press.

Yemtsov, R. (2008) "Through the Looking-Glass: What is behind official data on inequality in Russia over 1992-2003?" Paper presented at the $30^{\text {th }}$ General Conference of The International Association for Research in Income and Wealth, Portoroz, Slovenia, August 2008. 
Table 1

Lorenz-curves and inequality indices for the distribution of income in China 2002 and Russia 2003

\begin{tabular}{|c|c|c|c|c|c|c|}
\hline \multirow[t]{2}{*}{ Decile } & $\begin{array}{l}\text { Total } \\
\text { China }\end{array}$ & Russia & $\begin{array}{l}\text { Urban } \\
\text { China }\end{array}$ & Russia & $\begin{array}{l}\text { Rural } \\
\text { China }\end{array}$ & Russia \\
\hline & 2002 & 2003 & 2002 & 2003 & 2002 & 2003 \\
\hline 1 & 0.017 & 0.027 & 0.032 & 0.031 & 0.026 & 0.026 \\
\hline 2 & 0.045 & 0.071 & 0.079 & 0.079 & 0.067 & 0.070 \\
\hline 3 & 0.082 & 0.127 & 0.137 & 0.138 & 0.118 & 0.126 \\
\hline 4 & 0.129 & 0.193 & 0.205 & 0.207 & 0.180 & 0.194 \\
\hline 5 & 0.189 & 0.272 & 0.285 & 0.286 & 0.252 & 0.275 \\
\hline 6 & 0.266 & 0.363 & 0.376 & 0.377 & 0.336 & 0.369 \\
\hline 7 & 0.367 & 0.466 & 0.481 & 0.482 & 0.435 & 0.475 \\
\hline 8 & 0.500 & 0.591 & 0.604 & 0.602 & 0.554 & 0.599 \\
\hline 9 & 0.679 & 0.746 & 0.756 & 0.758 & 0.708 & 0.751 \\
\hline 10 & 1.000 & 1.000 & 1.000 & 1.000 & 1.000 & 1.000 \\
\hline \multicolumn{7}{|l|}{$\begin{array}{l}\text { Inequalit } \\
\mathrm{y} \text { indices }\end{array}$} \\
\hline Gini & 0.453 & 0.336 & 0.317 & 0.314 & 0.373 & 0.331 \\
\hline MLD & 0.350 & 0.198 & 0.168 & 0.167 & 0.235 & 0.200 \\
\hline Theil & 0.362 & 0.198 & 0.172 & 0.172 & 0.255 & 0.205 \\
\hline $\begin{array}{l}\text { Mean } \\
\text { value (in } \\
\text { local } \\
\text { currency) }\end{array}$ & 5912 & 3363 & 10023 & 3735 & 3283 & 2234 \\
\hline $\begin{array}{l}\text { Proportio } \\
\text { n of total } \\
\text { populatio } \\
\text { n in the } \\
\text { country }\end{array}$ & 100 & 100 & 39.1 & 75.2 & 60.9 & 24.8 \\
\hline $\begin{array}{l}\text { Number } \\
\text { of } \\
\text { observati } \\
\text { ons in } \\
\text { sample }\end{array}$ & 62244 & 107695 & 24275 & 74700 & 37969 & 32995 \\
\hline
\end{tabular}

Sources: Authors’ calculations from CHIP 2002 and NOBUS 2003. 
Table 2

Decomposing income inequality in China 2002 and Russia 2003 as a whole by urban and rural

\begin{tabular}{|c|c|c|c|c|}
\hline & $\begin{array}{l}\text { MLD } \\
\text { China }\end{array}$ & Russia & $\begin{array}{l}\text { Theil } \\
\text { China }\end{array}$ & Russia \\
\hline $\begin{array}{l}\text { Total inequality } \\
\text { (index values) }\end{array}$ & 0.362 & 0.198 & 0.350 & 0.198 \\
\hline $\begin{array}{l}\text { within urban } \\
\text { inequality } \\
\text { (index-value) }\end{array}$ & 0.168 & 0.167 & 0.172 & 0.172 \\
\hline $\begin{array}{l}\text { Sub group } \\
\text { population as } \\
\text { share of total } \\
\text { population }\end{array}$ & 0.391 & 0.752 & & \\
\hline $\begin{array}{l}\text { Subgroup } \\
\text { income share of } \\
\text { total income }\end{array}$ & & & 0.660 & 0.770 \\
\hline $\begin{array}{l}\text { Within rural } \\
\text { inequality } \\
\text { (index-value) }\end{array}$ & 0.235 & 0.200 & 0.255 & 0.205 \\
\hline $\begin{array}{l}\text { Population } \\
\text { share }\end{array}$ & 0.601 & 0.248 & & \\
\hline Income share & & & 0.340 & 0.230 \\
\hline $\begin{array}{l}\text { Between group } \\
\text { inequality } \\
\text { (index value) }\end{array}$ & 0.155 & 0.023 & 0.150 & 0.020 \\
\hline $\begin{array}{l}\text { As percent of } \\
\text { total inequality }\end{array}$ & 100 & 100 & 100 & 100 \\
\hline $\begin{array}{l}\text { Within urban } \\
\text { inequality }\end{array}$ & 18.2 & 63.6 & 32.7 & 72.6 \\
\hline $\begin{array}{l}\text { Within rural } \\
\text { inequality }\end{array}$ & 39.0 & 25.1 & 24.5 & 17.1 \\
\hline $\begin{array}{l}\text { Between urban } \\
\text { and rural } \\
\text { inequality }\end{array}$ & 42.8 & 11.4 & 42.8 & 10.3 \\
\hline $\begin{array}{l}\text { Urban to rural } \\
\text { income gap }\end{array}$ & 3.05 & 1.67 & 3.05 & 1.67 \\
\hline
\end{tabular}

Sources: Authors’ calculations from CHIP 2002 and NOBUS 2003. 
Table 3

Decomposition of the Gini-coefficient by income source in China 2002 as a whole and Russia 2003

\begin{tabular}{|c|c|c|c|c|}
\hline $\begin{array}{l}\text { Income } \\
\text { component }\end{array}$ & $\begin{array}{l}\text { Share of total } \\
\text { income } \\
\text { (percent) }\end{array}$ & $\begin{array}{l}\text { Concentration } \\
\text { coefficient }\end{array}$ & $\begin{array}{l}\text { Absolute } \\
\text { contribution }\end{array}$ & $\begin{array}{l}\text { Relative } \\
\text { contribution } \\
\text { (percent) }\end{array}$ \\
\hline \\
\hline Wages & 48.5 & 0.542 & 0.263 & 58.1 \\
\hline $\begin{array}{l}\text { Net income } \\
\text { from private } \\
\text { business }\end{array}$ & 5.7 & 0.287 & 0.016 & 3.6 \\
\hline Farming income & 13.0 & -0.138 & -0.018 & -4.0 \\
\hline Public transfers & 8.9 & 0.668 & 0.061 & 13.6 \\
\hline $\begin{array}{l}\text { Private } \\
\text { transfers }\end{array}$ & 6.1 & 0.205 & 0.012 & 2.8 \\
\hline $\begin{array}{l}\text { Imputed rents } \\
\text { and housing } \\
\text { subsidies }\end{array}$ & 17.6 & 0.550 & 0.097 & 21.4 \\
\hline Other & 0.1 & 1.650 & 0.02 & 4.6 \\
\hline Total & 100.0 & & 0.453 & 100.0 \\
\hline \multicolumn{5}{|c|}{ Russia } \\
\hline Wages & 49.5 & 0.419 & 0.207 & 61.7 \\
\hline $\begin{array}{l}\text { Net income } \\
\text { from private } \\
\text { business }\end{array}$ & 0.1 & 0.637 & 0.001 & 0.3 \\
\hline Farming income & 6.0 & 0.043 & 0.003 & 0.8 \\
\hline Public transfers & 17.5 & 0.180 & 0.032 & 9.4 \\
\hline $\begin{array}{l}\text { Private } \\
\text { transfers }\end{array}$ & 3.6 & 0.261 & 0.009 & 2.8 \\
\hline $\begin{array}{l}\text { Imputed rents } \\
\text { and housing } \\
\text { subsidies }\end{array}$ & 23.3 & 0.361 & 0.084 & 25.08 \\
\hline Other & - & - & - & - \\
\hline Total & 100.0 & & 0.336 & 100.0 \\
\hline
\end{tabular}

Sources: Authors’ calculations from CHIP 2002 and NOBUS 2003. 


\section{Table 4}

Decomposition of differences in Gini coefficient for China and Russia by income sources

\begin{tabular}{|c|c|c|c|c|c|c|c|}
\hline $\begin{array}{l}\text { Income } \\
\text { source }\end{array}$ & $\mathrm{s} * \mathrm{C}_{\mathrm{C}}$ & $\mathrm{s} * \mathrm{C}_{\mathrm{R}}$ & Difference & $\begin{array}{l}\mathrm{C}_{\mathrm{C}}\left(\mathrm{S}_{\mathrm{C}}-\mathrm{S}_{\mathrm{R}}\right. \\
)\end{array}$ & $\begin{array}{l}C_{R}\left(s_{C}-S_{R}\right. \\
)\end{array}$ & $\begin{array}{l}\mathrm{s}_{\mathrm{C}}\left(\mathrm{C}_{\mathrm{C}^{-}}\right. \\
\left.\mathrm{C}_{\mathrm{R}}\right)\end{array}$ & $\begin{array}{l}\mathrm{S}_{\mathrm{R}}\left(\mathrm{C}_{\mathrm{C}^{-}}\right. \\
\left.\mathrm{C}_{\mathrm{R}}\right)\end{array}$ \\
\hline Wages & 0.263 & 0.207 & 0.056 & -0.005 & -0.004 & 0.060 & 0.061 \\
\hline $\begin{array}{l}\text { Net } \\
\text { income } \\
\text { from } \\
\text { private } \\
\text { business }\end{array}$ & 0.016 & 0.001 & 0.015 & 0.016 & 0.036 & -0.020 & 0.000 \\
\hline $\begin{array}{l}\text { Farming } \\
\text { income }\end{array}$ & -0.018 & 0.003 & -0.021 & -0.010 & 0.003 & -0.024 & -0.011 \\
\hline $\begin{array}{l}\text { Public } \\
\text { transfers }\end{array}$ & 0.059 & 0.032 & 0.028 & -0.057 & -0.015 & 0.043 & 0.085 \\
\hline $\begin{array}{l}\text { Private } \\
\text { transfers }\end{array}$ & 0.012 & 0.009 & 0.003 & 0.005 & 0.007 & -0.003 & -0.002 \\
\hline $\begin{array}{l}\text { Imputed } \\
\text { rents and } \\
\text { housing } \\
\text { subsidies }\end{array}$ & 0.097 & 0.084 & 0.013 & -0.031 & -0.021 & 0.033 & 0.044 \\
\hline Other & 0.002 & - & 0.002 & & & & \\
\hline Total & 0.453 & 0.336 & 0.117 & & & & \\
\hline
\end{tabular}

Sources: Table 3. 
Table 5 Decomposition of the Gini-coefficient by income source in urban China and urban Russia

\begin{tabular}{|c|c|c|c|c|}
\hline $\begin{array}{l}\text { Income } \\
\text { component }\end{array}$ & $\begin{array}{l}\text { Share of total } \\
\text { income } \\
\text { China } 20\end{array}$ & $\begin{array}{l}\text { Concentration } \\
\text { coefficient }\end{array}$ & $\begin{array}{l}\text { Absolute } \\
\text { contribution }\end{array}$ & $\begin{array}{l}\text { Relative } \\
\text { contribution }\end{array}$ \\
\hline Wages & 58.1 & 0.300 & 0.175 & 55.5 \\
\hline $\begin{array}{l}\text { Net income } \\
\text { from private } \\
\text { business }\end{array}$ & 2.7 & 0.145 & 0.004 & 1.3 \\
\hline Farming income & - & - & - & - \\
\hline Public transfers & 14.5 & 0.254 & 0.037 & 11.7 \\
\hline $\begin{array}{l}\text { Private } \\
\text { transfers }\end{array}$ & 1.8 & 0.406 & 0.007 & 2.4 \\
\hline $\begin{array}{l}\text { Imputed rents } \\
\text { and housing } \\
\text { subsidies }\end{array}$ & 19.7 & 0.371 & 0.073 & 23.2 \\
\hline Other & 3.1 & 0.614 & 0.019 & 6.0 \\
\hline Total & 100.0 & & 0.317 & 100 \\
\hline \multicolumn{5}{|c|}{ Russia 2003} \\
\hline Wages & 52.4 & 0.383 & 0.201 & 64.0 \\
\hline $\begin{array}{l}\text { Net income } \\
\text { from private } \\
\text { business }\end{array}$ & 0.2 & 0.631 & 0.001 & 0.3 \\
\hline Farming income & 1.9 & 0.009 & 0.0002 & 0.1 \\
\hline Public transfers & 16.3 & 0.167 & 0.027 & 8.6 \\
\hline $\begin{array}{l}\text { Private } \\
\text { transfers }\end{array}$ & 3.3 & 0.260 & 0.009 & 2.8 \\
\hline $\begin{array}{l}\text { Imputed rents } \\
\text { and housing } \\
\text { subsidies }\end{array}$ & 26.0 & 0.293 & 0.076 & 24.2 \\
\hline Other & - & - & - & - \\
\hline Total & 100.0 & & 0.314 & 100.0 \\
\hline
\end{tabular}

Sources: Authors’ calculations from CHIP 2002 and NOBUS 2003. 
Table 6 Decomposition of the Gini-coefficient by income source in rural China 2002 and rural Russia 2003

\begin{tabular}{|c|c|c|c|c|}
\hline $\begin{array}{l}\text { Income } \\
\text { component }\end{array}$ & $\begin{array}{l}\text { Share of total } \\
\text { income } \\
\text { China }\end{array}$ & $\begin{array}{l}\text { Concentration } \\
\text { coefficient }\end{array}$ & $\begin{array}{l}\text { Absolute } \\
\text { contribution }\end{array}$ & $\begin{array}{l}\text { Relative } \\
\text { contribution }\end{array}$ \\
\hline Wages & 29.6 & 0.464 & 0.137 & 37.0 \\
\hline $\begin{array}{l}\text { Net income } \\
\text { from private } \\
\text { business }\end{array}$ & 11.7 & 0.723 & 0.085 & 22.8 \\
\hline Farming income & 38.4 & 0.136 & 0.052 & 14.1 \\
\hline Public transfers & -2.07 & -0.044 & 0.001 & 0.2 \\
\hline $\begin{array}{l}\text { Private } \\
\text { transfers } \\
\text { Imputed rents }\end{array}$ & 14.36 & 0.490 & 0.070 & 19.0 \\
\hline $\begin{array}{l}\text { and housing } \\
\text { subsidies }\end{array}$ & 13.6 & 0.348 & 0.047 & 12.8 \\
\hline Other & -5.6 & 0.386 & -0.022 & -5.8 \\
\hline Total & 100.0 Russia & & 0.371 & 100.0 \\
\hline Wages & 34.5 & 0.368 & 0.127 & 38.5 \\
\hline $\begin{array}{l}\text { Net income } \\
\text { from private } \\
\text { business }\end{array}$ & 0.1 & 0.275 & 0.0002 & 0.1 \\
\hline Farming income & 26.4 & 0.337 & 0.099 & 30.1 \\
\hline Public transfers & 24.0 & 0.236 & 0.057 & 17.2 \\
\hline $\begin{array}{l}\text { Private } \\
\text { transfers }\end{array}$ & 5.1 & 0.312 & 0.016 & 4.9 \\
\hline $\begin{array}{l}\text { Imputed rents } \\
\text { and housing } \\
\text { subsidies }\end{array}$ & 9.8 & 0.316 & 0.031 & 9.4 \\
\hline Other & - & - & - & - \\
\hline Total & 100.0 & & 0.331 & 100.0 \\
\hline
\end{tabular}

Sources: Authors' calculations from CHIP 2002 and NOBUS 2003. 
Table 7

Personal and household characteristics in the total sample and in the bottom 20 and top 20 percent of the sample for entire China 2002

\begin{tabular}{|c|c|c|c|}
\hline & Total sample & Bottom 20 percent & Top 20 percent \\
\hline \multicolumn{4}{|l|}{ Age of the individual } \\
\hline $0-18$ & 24.49 & 34.20 & 13.25 \\
\hline $19-25$ & 11.21 & 11.53 & 9.04 \\
\hline $26-35$ & 13.90 & 15.72 & 10.74 \\
\hline $36-45$ & 18.45 & 14.55 & 18.33 \\
\hline $46-55$ & 18.57 & 11.90 & 28.33 \\
\hline $56-64$ & 8.02 & 6.73 & 12.75 \\
\hline $66-74$ & 3.79 & 3.68 & 5.96 \\
\hline 75 - & 1.57 & 1.69 & 1.60 \\
\hline \multicolumn{4}{|l|}{$\begin{array}{l}\text { Education of the } \\
\text { household head }\end{array}$} \\
\hline Primary & 23.73 & 45.15 & 5.17 \\
\hline Incomplete secondary & 40.12 & 43.08 & 21.05 \\
\hline General secondary & 19.00 & 10.34 & 22.64 \\
\hline Vocational & 6.09 & 1.01 & 12.57 \\
\hline Higher & 11.06 & 0.42 & 38.57 \\
\hline \multicolumn{4}{|l|}{$\begin{array}{l}\text { Gender of household } \\
\text { head }\end{array}$} \\
\hline Male & 84.18 & 84.96 & 93.00 \\
\hline Female & 15.82 & 15.04 & 7.00 \\
\hline \multicolumn{4}{|l|}{$\begin{array}{l}\text { Gender of the } \\
\text { individual }\end{array}$} \\
\hline Male & 51.10 & 50.60 & 50.10 \\
\hline Female & 48.90 & 49.40 & 49.90 \\
\hline \multicolumn{4}{|l|}{$\begin{array}{l}\text { Number of } \\
\text { household members }\end{array}$} \\
\hline 1 & 0.14 & 0.02 & 0.71 \\
\hline 2 & 5.38 & 1.48 & 14.98 \\
\hline 3 & 23.55 & 6.89 & 37.09 \\
\hline 4 & 32.65 & 25.12 & 30.68 \\
\hline 5 & 22.06 & 32.20 & 10.85 \\
\hline $6+$ & 16.42 & 34.29 & 5.69 \\
\hline \multicolumn{4}{|l|}{ Urban / Rural } \\
\hline Urban & 39.0 & 0.65 & 91.30 \\
\hline Rural & 61.0 & 99.35 & 8.70 \\
\hline \multicolumn{4}{|l|}{ Region } \\
\hline East & 31.08 & 8.83 & 66.03 \\
\hline Central & 41.32 & 39.09 & 18.57 \\
\hline West & 27.60 & 52.07 & 15.40 \\
\hline
\end{tabular}

Sample size / $\quad 62235$

Sources: Authors’ calculations from CHIP 2002 . 
Table 8

Personal and household characteristics in the total sample and in the bottom 20 and top 20 percent of the sample for the whole of Russia 2003

Age of the individual

$0-18$

$19-25$

$26-35$

$36-45$

$46-55$

$56-64$

$66-74$

75 -

Education of the

household head

Primary

Incomplete secondary

General secondary

Vocational

Higher

Gender of household

head

Male

Female

Gender of the

individual

Male

Female

Number of

household members

1

2

3

4

5

$6+$

Urban / Rural

Urban

Rural

Region

Central

North-East

South

Volga

Ural

Siberia

Far East
Total sample

20.96

9.88

12.32

14.60

16.20

10.64

10.21

5.17

8.64

10.57

46.39

11.47

22.38

59.63

40.37

43.69

56.31

9.15

24.35

27.82

25.43

10.07

3.19

75.18

24.82

26.12

10.34

13.61

22.10

8.84

14.24

4.75
Bottom 20 percent

34.03

7.88

13.85

17.26

11.74

5.23

5.74

2.51

12.43

14.40

51.18

12.71

9.28

53.07

46.93

45.41

54.59

3.36

12.28

22.79

32.74

20.39

8.44

49.40

50.60

15.12

4.77

22.65

32.00

6.80

15.82

2.83
Top 20 percent

10.51

9.46

13.18

12.88

23.08

13.76

10.12

5.74

3.89

6.34

41.49

9.85

38.43

62.91

37.09

42.88

57.12

18.26

31.30

31.04

15.47

3.50

0.42

92.99

7.01

39.01

18.53

3.99

9.86

10.77

11.10

6.73

Sources: Authors' calculations from NOBUS 2003. 
Table 9

Estimates of semilog income functions for China 2002 and Russia 2003 (dependent variable: log total income)

\begin{tabular}{|c|c|c|c|c|}
\hline & China & Std Error & Russia & Std. Error \\
\hline \multicolumn{5}{|l|}{$\begin{array}{l}\text { Age of the } \\
\text { individual }\end{array}$} \\
\hline $0-18$ & - & & - & \\
\hline $19-25$ & $0.1081^{* * *}$ & 0.0079 & $0.16991^{* * *}$ & 0.00606 \\
\hline $26-35$ & $0.0303^{* * *}$ & 0.0074 & $0.11658^{* * *}$ & 0.00565 \\
\hline $36-45$ & $0.0479 * * *$ & 0.0068 & $0.10180^{* * *}$ & 0.00563 \\
\hline $46-55$ & $0.1442^{* * *}$ & 0.0069 & $0.23749^{* * *}$ & 0.00533 \\
\hline $56-64$ & $0.1205^{* * *}$ & 0.0092 & $0.22084^{* * *}$ & 0.00638 \\
\hline $66-74$ & $0.0916 * * *$ & 0.0123 & $0.15806^{* * *}$ & 0.00685 \\
\hline $75-$ & $0.0497 * * *$ & 0.0172 & $0.20032^{* * *}$ & 0.00844 \\
\hline \multicolumn{5}{|l|}{$\begin{array}{l}\text { Education of the } \\
\text { household head }\end{array}$} \\
\hline Primary & - & & - & \\
\hline $\begin{array}{l}\text { Incomplete } \\
\text { secondary }\end{array}$ & $0.0858 * * *$ & 0.0058 & $0.04373^{* * *}$ & 0.00720 \\
\hline General secondary & $0.2019 * * *$ & 0.0072 & $0.19703^{* * *}$ & 0.00621 \\
\hline Vocational & $0.3323 * * *$ & 0.0105 & $0.18557^{* * *}$ & 0.00743 \\
\hline Higher & $0.5113 * * *$ & 0.0092 & $0.44335^{* * *}$ & 0.00673 \\
\hline \multicolumn{5}{|l|}{$\begin{array}{l}\text { Gender of } \\
\text { individual }\end{array}$} \\
\hline Male & - & & - & \\
\hline Female & $-0.0084^{* * *}$ & 0.0044 & $-0.03201^{* * *}$ & 0.00319 \\
\hline $\begin{array}{l}\text { Number of } \\
\text { household members }\end{array}$ & - & & & \\
\hline 1 & - & & - & \\
\hline 2 & $-0.3477 * * *$ & 0.0584 & $-0.23575^{* * *}$ & 0.00623 \\
\hline 3 & $-0.5282 * * *$ & 0.0579 & $-0.36224^{* * *}$ & 0.00662 \\
\hline 4 & $-0.6472 * * *$ & 0.0579 & $-0.51000^{* * * *}$ & 0.00683 \\
\hline 5 & $-0.7896 * * *$ & 0.0580 & $-0.64669^{* * *}$ & 0.00779 \\
\hline $6+$ & $-0.8797 * * *$ & 0.0580 & $-0.75598^{* * *}$ & 0.01070 \\
\hline \multicolumn{5}{|l|}{ Urban / Rural } \\
\hline Urban & $0.8962 * * *$ & 0.0054 & $0.37928^{* * *}$ & 0.00381 \\
\hline Rural & - & & - & \\
\hline \multicolumn{5}{|l|}{ Region } \\
\hline \multicolumn{5}{|l|}{ Russia } \\
\hline$\overline{\text { Central }}$ & & & - & \\
\hline North-West & & & $0.06624^{* * *}$ & 0.00574 \\
\hline South & & & $-0.35510^{* * *}$ & 0.00528 \\
\hline Volga & & & $-0.32740^{* * *}$ & 0.00454 \\
\hline Ural & & & $-0.00170^{* * * *}$ & 0.00609 \\
\hline Siberia & & & $-0.17378^{* * *}$ & 0.00517 \\
\hline Far East & & & $0.04387^{* * *}$ & 0.00780 \\
\hline \multicolumn{5}{|l|}{ China } \\
\hline$\overline{\text { East }}$ & - & & & \\
\hline Central & $-0.4495 * * *$ & 0.0052 & & \\
\hline West & $-0.5556 * * *$ & 0.0058 & & \\
\hline Intercept & $8.7727 * * *$ & 0.0583 & 8.16777 & 0.01078 \\
\hline $\mathbf{R}^{2}$ & 0.597 & & 0.3632 & \\
\hline $\mathbf{N}$ & 62235 & & 107680 & \\
\hline
\end{tabular}




\section{Table 10}

Predicted income (as percent of mean income) for selected individuals living in different rural regions and urban regions in China and Russia

$\begin{array}{lll}\text { China } & \text { Russia } & \\ \text { Rural } & \text { Urban } & \text { Rural }\end{array}$

a) A typical individual, e.g., living in a household with size 3 , the head has a middle level education, age of the individual is $36-45$, and it is a male

Rich region

Poor region

b) Same as a) but household size equal to 6

Rich region

Poor region

c) same as a) but education of household head equal to high

Rich region

Poor region

d) same as a) but age 66- 75

Rich region

Poor region

e) same as a) but age -19

Rich region

Poor region
196

140

154

97

253

196

205

148

194

138
77

50

52

34

76

50

Source: Calculations based on estimates presented in Table 9 
Figure 1

The distribution of individuals by fraction of mean income in China as a whole and Russia as a whole

a) China 2002 as a whole

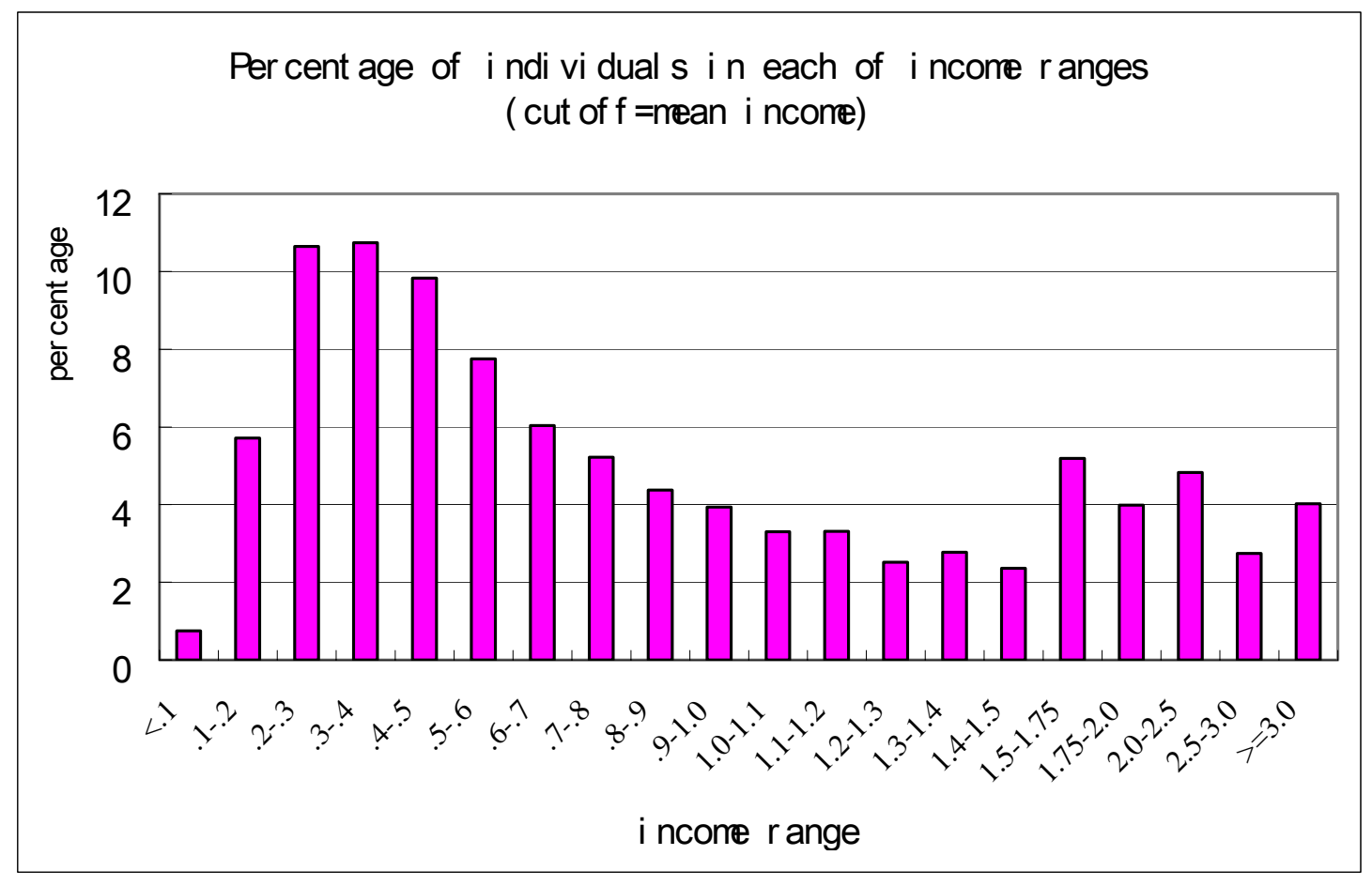

b) Russia as a whole

Frequency of individuals in income range in Russia (cut off=national income)

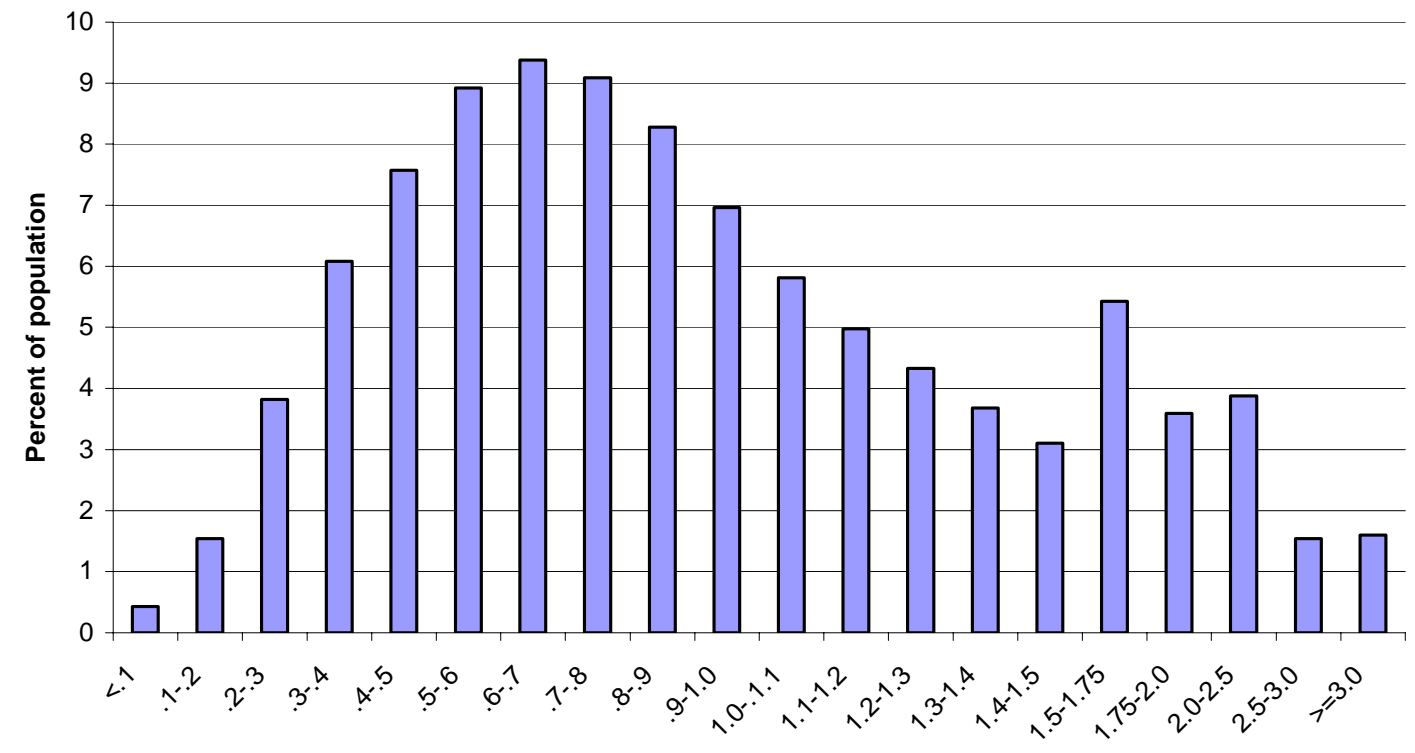


Figure 2

The distribution of individuals by fractions of mean income in urban and rural China

a) urban China

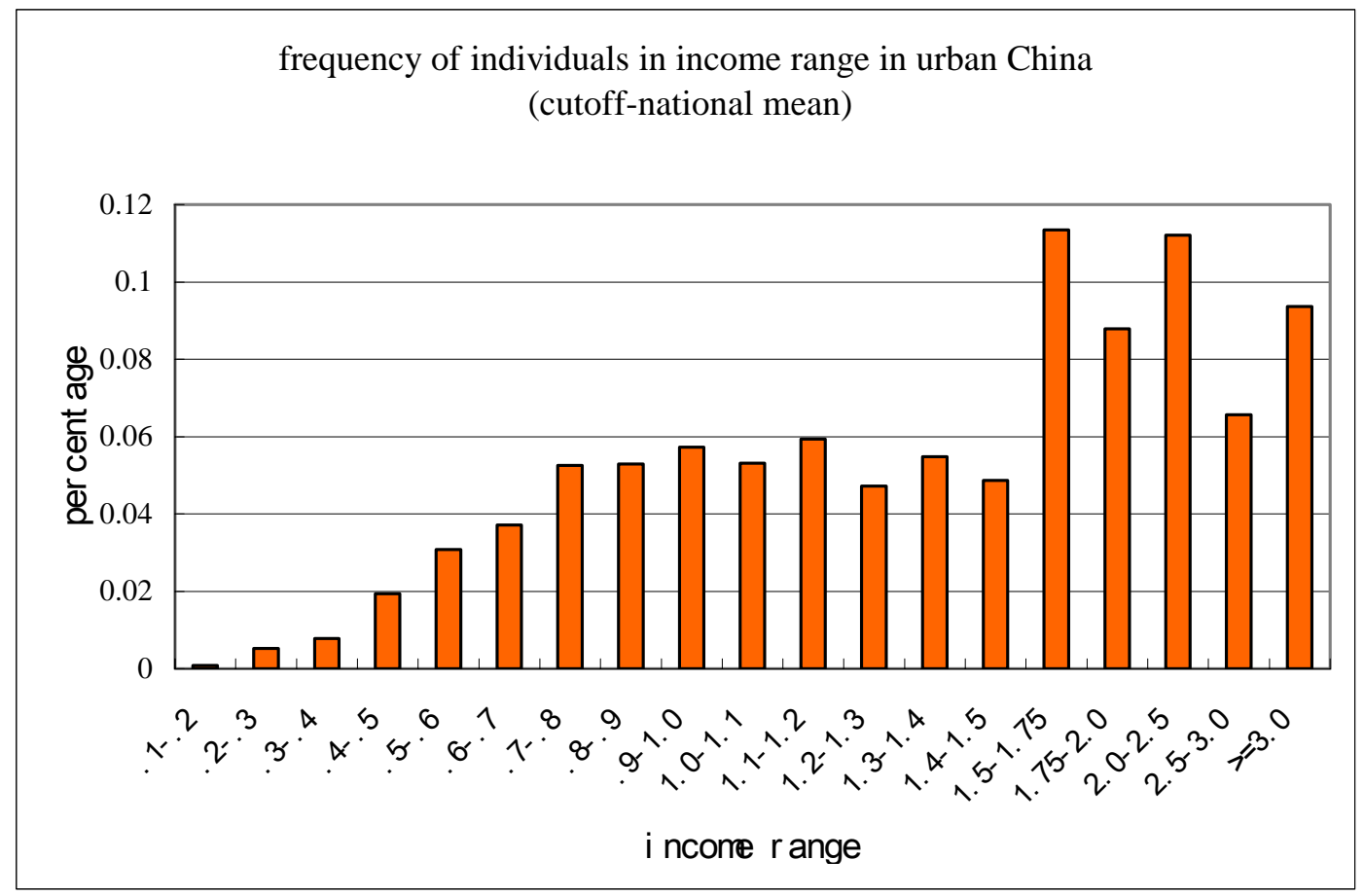

b) rural China

Fr equency of i ndi vi dual s i $n$ i ncome range i $n$ rural Chi na ( cut of $\mathrm{f}=$ nat $\mathrm{i}$ onal mean)

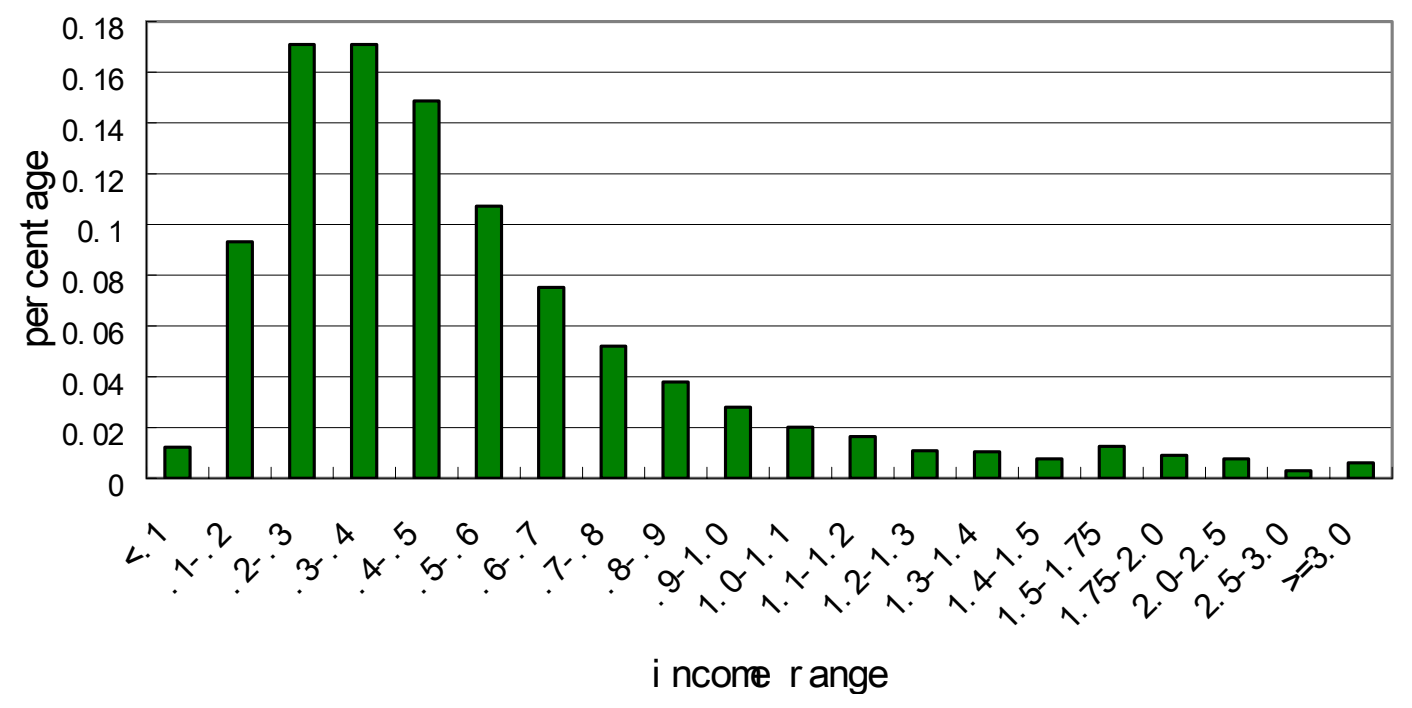


Figure 3

The distribution of individuals by fraction of mean income in urban Russia and rural Russia.

Frequency of individuals in income range in urban Russia (cut off=national mean)

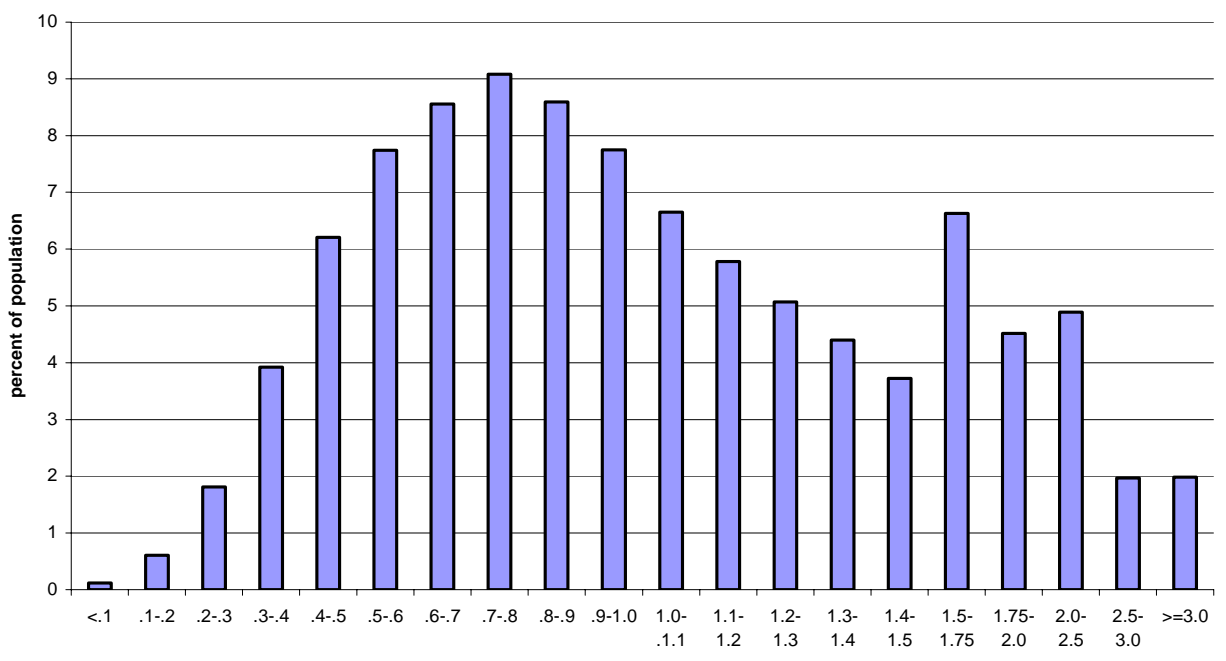

Frequency of individual in income range in rural Russia (cut off=national mean)

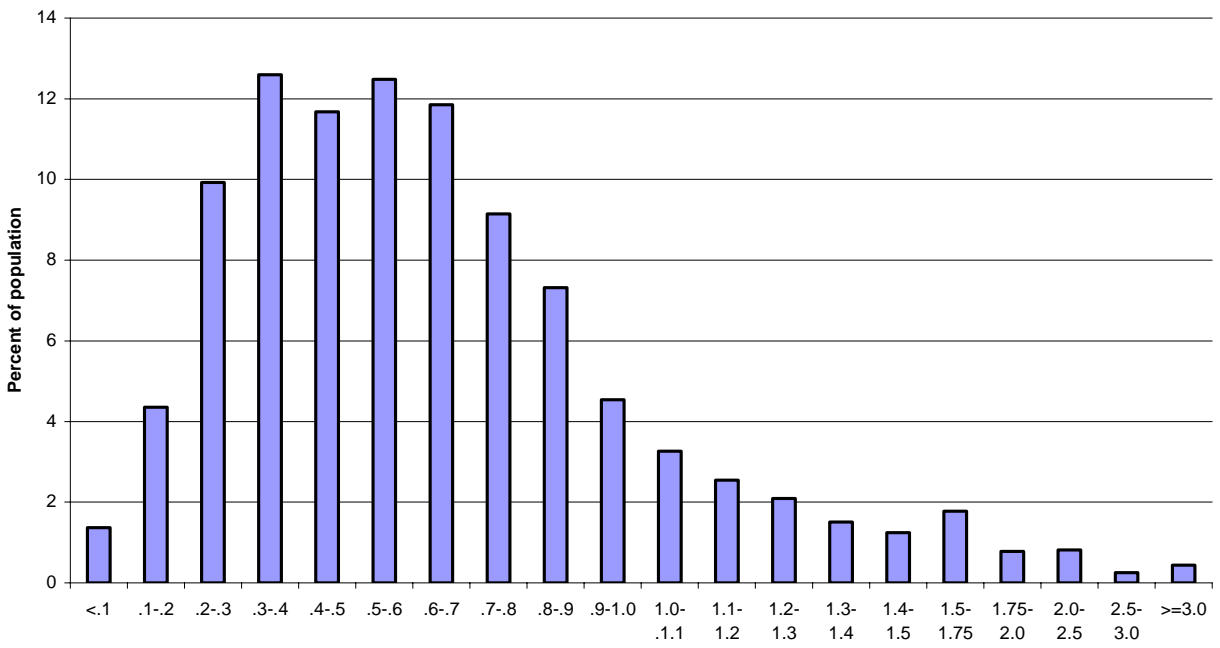


${ }^{1}$ Earlier versions of this paper were presented at the International Conference on Experiences and Challenges in Measuring National Income and Wealth in Transition Economies, September 19-21, 2007, Beijing, China jointly organised by the International Association for Research on Income and Wealth (IARIW) and the National Bureau of Statistics (NBS), China as well as at Chinese Economist Society 2008 Annual Conference, Tianjin, China, April 17 - 19 2008. We thank for useful comments received at those occasions and from Katarina Katz..

${ }^{2}$ Galbraith et al (2004) use official measures of income by region and sector in Russia 1990-2001 and China 1987- 1999/2000 and report increasing inequality in both countries. However, the authors do not compare levels of inequality across countries. Mitra and Yemtsov (2006) survey the recent literature on income inequality in countries in transition and note, for example, that the urban to rural income gap in China is much higher than in Russia. In the meta study of countries in transition, Fleisher et al (2005) investigates rates of return to education in the labour market. Rates of return to education are reported to have increased in China as well as in Russia, and to be higher in the second country. The latter is also shown in Gustafsson et al (2001) based on analysing harmonised microdata for cities from the end of the 80s. Starting with Nee (1989), in the sociological literature there are several studies of income accrued to elites in China as well as in Russia. A meta study on this literature (but not including rural China) is Verhoven (2005). However, we have not found any attempts in this literature to compare income of elites in China and Russia using harmonised microdata.

${ }^{3}$ For more on this see for example Whyte (2010).

${ }^{4}$ Recent writings on the development of income inequality in China include UNDP (2005), Ravallion and Chen (2007), Gustafsson et al (2008). See also the special issues of Journal of Comparative Economics, 2006 (no 4), Review of Income and Wealth (no 1) 2007 and Economics of Transition (no 1) 2008. On the urban to rural income gap in China see, for example, Knight and Song (1999) and Sicular et al (2007).

${ }^{5}$ Atkinson and Micklewright (1992) discuss limitations of the official statistics during the Soviet era and Yemtsov (2005) reports the changes during transition. Milanovic (1988) reports results for the period from 1989 to 1994 using official data and the Russian Longitudinal Monitoring Survey (RLMS). Commander et al. (1999) study the period 1992 to 1996 using RLMS. Mikheeva (1999) analysed the development of average incomes of regions during the 1990s, and Carluer (2005) for the period 1985 to 1999. Sheviakov and Kiruta (2001) studied official household data 1994, 1995, 1996 and 1997 and Kislitsyna (2003) investigated inequality in household income using RLMS 1992, 1994, 1996, 1998 and 2000.

${ }^{6}$ For more information on the Chinese surveys see Li et al. (2008).

${ }^{7}$ Khan and Riskn (2008) show for 2002 that including a sample of rural to urban immigrants causes the Gini coefficient to increase from 0.318 to 0.338 . However, the corresponding Ginis for the entire country of China are very close to each other: 0.450 (not including rural to urban migrants) and 0.448 (including rural to urban migrants).

${ }^{8}$ The following urban strata were defined: cities with populations of: 1 million people and more; 500999,9 thousand people; 250-499,9 thousand people; 100-249,9 thousand people; 50-99,9 thousand people; 20-49,9 thousand people; up to 20 thousand people.

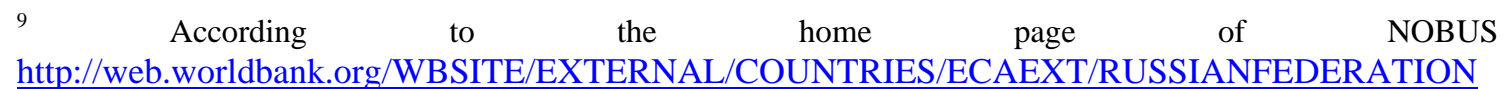


EXTN/0,,contentMDK:20919706 pagePK:141137 piPK:141127 theSitePK:305600,00.html accessed March 20, 2008.

${ }^{10}$ World Bank (2005B) reports Ginis for Russia 1997 to 2002 for three alternative definitions and the drop in Gini between 1998 and 2002 is not more than two to three percent.

${ }^{11}$ The Gini increases from 33.6 percent as reported in Section 7 to 40.7 percent.

${ }^{12}$ Many researchers have used Russia Longitudinal Monitoring Survey (RLMS) for studying income inequality in Russia. Compared to this data source, NOBUS has the advantages of considerably larger sample size, a purposeful sampling strategy, and includes a larger number of questions on income components. In footnote 19 we compare our estimate of the Gini for Russia 2002 with other estimates for approximately the same point in time

${ }^{13}$ Often household income surveys underestimate true income inequality due no non-reporting of income; this is particularly true for households with the lowest and the highest incomes. Based on differences in non-response rates across the two surveys as well as comparing our calculations with previous reports on income inequality in Russia during transition, one could hypothesise that underestimation of inequality is larger in the Russian data. However, the Russian data is collected for monthly income while for China, the income data is for a full year; monthly income is typically more unequally distributed than annual income.

${ }^{14}$ For each country we derived imputed rents based on respondents' answers to questions on their estimate of the market rent for the housing they own. We estimated regression models in which the answers were related to region, type of settlement, total housing area, type of household and communal service. This provided us with a table for each country, and based on this we imputed rents for each household.

${ }^{15}$ Brandt and Holz (2006) have developed a spatial price index for China and it is used by, for example, Sicular et al (2007) for studying the urban - rural income gap using the same data as this study. However, we are not aware of any similar index for Russia. We chose to treat the two samples identically in this respect and therefore do not adjust income for regional price differences in any of the samples.

${ }^{16}$ In a sensitivity analysis we instead divide each household with its' equivalence number applying an often used equivalence scale according to which the first adult is assumed the value 1.0, each other adults a value of 0.7 and each child 0.5 . It turns out that the results are qualitatively very similar. For example the Gini coefficient for China as a whole is under this assumption 0.444, not 0.453 as reported in Table 1, and the Gini coefficient for Russia assumes the value of 0.321 , not 0.336 as reported in Table 1.

${ }^{17}$ In Table 7 we report that 91 percent of persons in the top quintile in China are urban while only 1 percent in the bottom quintile are urban. The corresponding percentages for Russia reported in Table 8 are 93 percent and 49 percent.

${ }^{18}$ Please note that we are comparing the distribution of income in the two countries, not the distribution of wealth. Although one can suppose a positive relation between income and wealth to exist within a population, savings from high earnings are most likely not the most important channel to have generated very high wealth holdings in the two countries under study. Forbes (http://www.forbes.com/billionaires/) lists 793 billionaires in the World 2006. In the list there are a larger number of Russians (33 citizens) than Chinese (8 citizens), and the highest-ranked Russian person is at a higher position (number 11) then the highest-ranked Chinese (number 451).

${ }^{19}$ See http://www.wider.unu.edu/wiid/wiid.htm 
${ }^{20}$ The lowest estimate is 34.6 percent for 1997 and 1998 based on household budget surveys and refers to expenditures. These estimates are based on data from Goskomstat, but no details are available on the surveys. The latest estimate of the Gini coefficient in the WIDER database, 42.2, percent, refers to 2001 and comes from the TransMONEE 2004 Data Base at United Nations Children's Fund, IRC Florence (the 2006 version of the TransMONEE, see http://www.uniceficdc.org/resources/transmonee.html does not contain newer estimates for Russia). The website of Luxembourg Income Study reports a Gini for Russia 2000 of 43.4 based on Russian Longitudinal Monitoring Survey (RLMS, see http://www.cpc.unc.edu/rlms/). Gustafsson and Nivorozhkina (2005) report a Gini of 35.6 for the city of Taganrog in 2000. World Bank (2005B) reports Ginis 1997 to 2002 for three alternative definitions of consumption. In 2002 the lowest Gini is 33.0 obtained for consumption divided by a poverty line, and is thus rather close to our estimate for Russia 33.6 based on income. World Bank (2005A) reports a Gini for Russia 2003 (based on consumption) of 32.0.

${ }^{21}$ See http://www.lisproject.org

${ }^{22}$ For example: Austria, Czech Republic, Netherlands, Norway, Slovak Republic and Sweden. The Ginis reported on the Website of LIS are computed using a more narrow definition of income (as it does not include imputed rents of owner occupied housing and the value of benefits in kind) and another equivalence scale than that used in this study.

${ }^{23}$ Please note that although the two indices provide the same picture on the relative importance of between urban to rural inequality in both countries, for China they give rather different pictures on the relative importance of within urban and within rural inequality. MLD, which uses persons as weights, attributes a larger proportion of inequality to the more populous rural China. The Theil index, which uses income as weights, attributes most of inequality to the richer urban part.

${ }^{24}$ Secondi (1997) analysing CHIP data for rural China 1988 reports receipt of private transfers as well as sums received to be positively related to county income. He also concludes that most money flows appear to be transfers from adult children to elderly parents and remittances from migrants.

${ }^{25}$ However, note that we have not adjusted for possible spatial differences in consumer prices. To the extent that consumer prices and income are positively correlated, we are more likely overestimating spatial income differences than underestimating them.

${ }^{26}$ See Fleisher et al (2005). 